JAMP: Jurnal Adminitrasi dan Manajemen Pendidikan

Volume 2 Nomor 2 Juni 2019, Hal : 65-72

Tersedia Online di http://journal2.um.ac.id/index.php/jamp/

ISSN 2615-8574 (online)

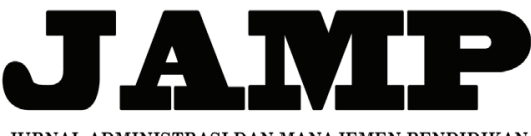

JURNAL ADMINISTRASI DAN MANAJEMEN PENDIDIKAN

\title{
KEPEMIMPINAN KEPALA SEKOLAH DAN KIAI DALAM PENGEMBANGAN SEKOLAH BERBASIS PONDOK PESANTREN
}

\author{
Muhammad Romady \\ Sultoni \\ Juharyanto \\ romacliquerz@gmail.com \\ Universitas Negeri Malang, Jl. Semarang 5 Malang 65145
}

\begin{abstract}
The main objective of research to know about (1) The profile of principal and kiai (2) the role of principal as a leadership of change in improving the quality of education, (2) the principal's strategy as a leadership of change in improving the quality of education, (3) innovation principal as a leadership of change in improving the quality of education, (4) factors supporting of change, and (5) inhibiting factors of change. This research uses a qualitative approach with case study. Place the research in SMP An-Nur Bululawang Malang. Data collection techniques through in-depth interviews, field observation and documentation. Analytical techniques used are reduction, data display, and data verification. Results from this research (1) the role of headmaster, (2) the strategy used by the principal, (3) innovations made by the principal, (4) the factors that support (5) the inhibiting factors.
\end{abstract}

Keyword: leadership of change, quality of education

\begin{abstract}
Abstrak: Tujuan penelitian ini adalah untuk mengetahui (1) Profil kepala sekolah dan kiai, (2) peran kepala sekolah dan kiai dalam pengembangan sekolah berbasis pondok pesantren, (3) strategi kepala sekolah dan kiai dalam pengembangan sekolah berbasis pondok pesantren, (4) kinerja yang dihasilkan kepala sekolah dan kiai dalam pengembangan sekolah berbasis pondok pesantren, (5) faktor pendukung pengembangan, dan (6) faktor penghambat pengembangan. Penelitian ini menggunakan rancangan pendekatan kualitatif, dengan rancangan penelitian studi kasus. Lokasi penelitian ini yaitu di SMP An-Nur Bululawang Malang. Teknik pengumpulan data melalui wawancara secara mendalam, observasi lapangan serta dokumentasi. Teknik analisis yang digunakan yaitu reduksi, display data, dan verifikasi data. Hasil dari penelitian ini (1) Riwayat pendidikan, (2) peran kepala sekolah dan kiai, (3) strategi yang digunakan kepala sekolah, (4) kinerja yang dihasilkan kepala sekolah dan kiai, (5) faktor pendukung pengembangan berasal dari internal, (5) faktor penghambat pengembangan.
\end{abstract}

Kata Kunci: Kepemimpinan pengembangan, sekolah berbasis pondok pesantren, kualitas pendidikan 
Kepemimpinan merupakan kunci utama dalam menentukan keberhasilan suatu organisasi. Seorang pemimpin harus mampu mempengaruhi anggotanya untuk mencapai tujuan yang hendak dicapai dan telah ditentukan sebelumnya. Seorang pemimpin juga harus memiliki kepribadian dan kecakapan yang baik dalam membina atau memimpin organisasi yang dipimpin. Hal tersebut sangat berguna dalam mengelola sumber daya potensial yang ada di dalam organisasinya. Pemimpin di lembaga satuan pendidikan adalah kepala sekolah. Kepala sekolah sebagai pemimpin pada lembaga pendidikan memiliki peranan penting dalam memberdayakan sumber daya yang ada di sekolahnya. Jika seorang kepala sekolah mampu menggunakan potensi sumber daya secara bijaksana, maka proses pendidikan dapat berjalan dengan baik dan benar. Menurut Wahjosumidjo (2011: 17) kepemimpinan diterjemahkan ke dalam istilah sifat-sifat, perilaku pribadi, pengaruh terhadap orang lain, pola-pola interaksi, hubungan kerja sama antar peran, kedudukan dari satu jabatan administrasi, dan persepsi dari lain-lain tentang legitimasi pengaruh.

Umat beragama dewasa ini di Indonesia juga memiliki peranan dalam pengembangan pendidikan nasional, pengembangan pendidikan nasional sekarang ini harus ditunjang dengan pendidikan agama, supaya masyarakat Indonesia menjadi warga yang bermoral dan bertanggung jawab. Pendidikan berbasis pondok pesantren adalah salah satu lembaga pendidikan yang juga memiliki peran membangun pendidikan nasional. Pada lingkup pondok pesantren yang bertugas sebagai pemimpin pondok adalah seorang kiai. Kiai adalah tokoh sentral dalam pondok pesantren, karena memiliki tanggungjawab sebagai pengasuh pondok.

Peran kepala sekolah sangat dibutuhkan dalam proses pengembangan. Dalam hal ini kepala sekolah berperan menentukan keberhasilan dan kegagalan lembaga pendidikan ketika melakukan pengembangan. Menurut Andriani (2008: 59-60) menjelaskan peran kepala sekolah sebagai katalisator yaitu seseorang yang menyebabkan terjadinya pengembangan, bertugas meyakinkan warga sekolah atas urgensi kebutuhan pengembangan sekolah guna peningkatan mutu pendidikan. Perubahan tersebut dapat dikelola oleh pemimpin melalui kepemimpinannya. Wibowo (dalam Supriyanto, 2009), menyebutkan beberapa peran pemimpin dalam membawa perubahan kepada organisasinya meliputi; (a) menciptakan hubungan kerja efektif; (b) pergeseran fungsi manajer; (c) memimpin dengan contoh; (d) mempengaruhi orang lain; (e) megembangkan team work; (f) melibatkan bawahan dalam pengambilan keputusan; (g) menjadikan pemberdayaan kepada bawahan sebagai way of life; dan (h) membangun komitmen.

Setiap pemimpin dalam yang melakukan pengembangan organisasi perlu memiliki strategi agar proses pengembangan dapat berjalan sesuai dengan harapan. Tujuan utamanya supaya apa yang menjadi target pimpinan dalam mengembangkan organisasi dapat dilalui dengan lancar. Ketidakmampuan pemimpin dalam menyusun strategi dapat berakibat pada kegagalan. Menurut Wibowo (2012: 343347) ada beberapa strategi yang dapat digunakan oleh pemimpin dalam mengembangkan organisasi antara lain, a) melakukan akselerasi (percepatan) perubahan di masa depan; b) pemimpin harus menjadi sentral (pusaran/motor) perubahan; c) memiliki langkah-langkah yang jelas dalam memipin perubahan; d) menyeimbangkan antara perubahan dan kontinuitas; dan e) meningkatkan kepuasan pekerja.

. Melalui peran dan strategi yang digunakan oleh pemimpin, maka akan tercipta kinerja yang berdampak pada peningkatan kualitas pendidikan. Kinerja adalah produk yang dihasilkan oleh individu dalam kurun waktu yang ditentukan dengan kriteria yang ditentukan. Menurut Prawirosentono (2002: 23) kinerja adalah usaha yang dilakukan oleh seseorang dari pekerjaan yang telah dikerjakan sesuai tugas yang diberikan oleh suatu organisasi sesuai dengan wewenang dan tanggung jawab masing-masing dalam rangka mencapai tujuan organisasi secara legal, tidak melanggar hukum dan sesuai dengan moral maupun etika. Namun demikian, untuk dalam melakukan pengembangan pasti terdapat kendala yang besar yang menghambat pemimpin. Kaufmant dalam bukunya Limits Of Organization Change (1985:8) mengatakan bahwa kegagalan suatu organisasi dalam melakukan perubahan dapat disebabkan oleh beberapa faktor yaitu (1) hasrat untuk mempertahankan kestabilan hidup bersama, (2) pertimbangan atas lawan-lawan yang mungkin dihadapi untuk mengadakan perubahan, dan (3) ketidakmampuan untuk mengadakan perubahan. Sedangkan Robbins (2006:767) menyebutkan beberapa sumber-sumber penolakan yang bersifat individual yaitu (1) kebiasaan, ada sebagian individu menolak perubahan karena sudah terbiasa dengan "gaya lama" yang ia jalankan, (2) keamanan, orang dengan kebutuhan 
yang tinggi akan keamanan cenderung menolak perubahan karena akan mengancam perasaan aman mereka, dan (3) faktor-faktor ekonomi, sumber penolakan ini adalah kekhawatiran bahwa perubahan itu akan mengurangi penghasilan seseorang. Hambatan-hambatan tersebut pasti akan ditemui oleh pemimpin organisasi dalam melakukan perubahan. Untuk itu pemimpin harus mampu mengantisipasi dan mengatasi hambatan tersebut agar perubahan yang dilakukan dapat berhasil.

\section{METODE}

Penelitian ini menggunakan pendekatan kualitataif, dengan jenis penelitian studi kasus. Teknik pengumpulan data yang digunakan pada penelitian ini adalah wawancara secara mendalam, observasi lapangan, dan dokumentasi. Analisis yang dilakukan dalam penelitian ini bersamaan dengan pengumpulan data saat di lapangan. Dalam analisis data, peneliti mereduksi data yang telah didapatkan di lapangan, lalu memilah setiap data sesuai fokus penelitian dan selanjutnya membuat kesimpulan pada masing-masing fokus. Pengecekan keabsahan data pada penelitian ini menggunakan teknik triangulasi (sumber dan metode/teknik), ketekunan pengamatan, serta pengecekan anggota.

\section{HASIL}

Seseorang yang berprofesi sebagai kepala sekolah tidak bisa secara langsung tiba-tiba menjadi kepala sekolah, ada proses yang harus ditempuh, ada pengalaman yang diperoleh, ada jenjang karir yang dicapai, dan ada usaha yang dilakukan, diantaranya adalah memiliki riwayat pendidikan kepala Sekolah: a) MI Kudat Lor; b) Mts Gondanglegi; c)MA An-nur; d) STISIA Jakarta; e) Univ.Darul ulum, memiliki pengalaman organisasi kepala sekolah: a) MWC NU; b) Organisasi Komite; c) Organisasi Kepala Sekolah, memiliki pengalaman kerja kepala sekolah: Menjadi guru Pendidikan Agama, dan kemudian usaha yang dimiliki kepala sekolah: a) Pertanian; b) Peternakan; c) Toko. Bagi kiai pondok pesantren memperbanyak ilmu untuk diajarkan kepada ummat hukumnya adalah wajib. Kiai pondok pesantren An-Nur juga melalui proses yang panjang sebelum pada akhirnya menjadi pengasuh seperti sekarang ini yaitu riwayat pendidikan kiai: a)MI Al-Khoiryiyyah; b) Mts AlKhoiriyyah; c) MA An-Nur; d) STAIN Malang S1 Sastra Arab; e) S2 Universitas Islam Lamongan ; f) S3 IAIN Sunan Ampel Surabaya, pengalaman organisasi kiai: a) MWC NU; b) PMII, pengalaman kerja kiai: a) Tenaga pengajar bahasa arab di PP An-nur; b) Guru tafsir dan tasawuf pondok pesantren An-Nur; c) Dosen MK Ulum-AlQuran STIT Raden Rahmad Kepanjen; d) Direktur Ma'had Al-Aly Annur; e) Tenaga pengajar umul qur'an An-Nur, usaha yang dimiliki kiai: a) Pertanian; b) Saham; c) Kerjasama Travel Umroh. Peran kepala sekolah dan kiai sebagai pemimpin pengembangan dalam peningkatan kualitas pendidikan adalah (1) manajerial SDM yang ada di sekolah, (2) pengawas kegiatan di pondok pesantren dan sekolah yang berada dibawah naungan pesantren, (3) pengambil keputusan tertinggi, (4) Penanggung jawab program yang ada disekolah, (5) sebagai model (Uswatun Hasanah) kepada masyarakat sekolah dan pesantren, (6) motivator bagi guru dan staff, (7) patner kerja bagi guru dan staff.

Strategi kepala sekolah dan kiai agar pengembangan yang dibawanya mengarah pada peningkatan kualitas pendidikan yaitu dengan cara (1) memperbaiki manajemen sarana dan prasarana seperti gedung dan fasilitas kelas dan kantor, (2) memperbaiki manajemen sumber daya manusia dengan memberikan pelatihan, (3) menumbuhkan budaya sekolah ala pondok pesantren, (4) melakukan supervisi, (5) menjaga komunikasi dengan kepala sekolah untuk mengawasi perkembangan sekolah.

Peran dan strategi pengembangan tersebut melahirkan kinerja-kinerja baru untuk menjawab permasalah dan kebutuhan baik sekolah itu sendiri ataupun pondok pesantren. 
Kinerja yang dihasilkan oleh kepala sekolah dan kiai adalah (1) menyelenggarakan program kelas idaman, (2) mendapatkan status sekolah akreditasi-A, (3) E-Report sebagai bahan evaluasi online, (4) mendirikan pondok khusus penghafal Al-Qur'an, (5) mendapatkan penghargaan akademik dan non-akademik.

Faktor yang mendorong terjadinya pengembangan di SMP An-Nur Bululawang yaitu berasal dari internal dan eksternal sekolah. Faktor internal yaitu berasal dari (1) kepemimpinan kepala sekolah dan kiai, (2) dukungan pondok pesantren, (3) sarana prasarana, (4) wali murid dan alumni. Sedangkan faktor eksternal terjadinya pengembangan yaitu dari (1) kebutuhan masyarakat terhadap pendidikan formal dan agama tinggi, (2) peserta didik berprestasi namun tidak mempunyai biaya, (3) kesuksesan lembaga pendidikan lain. Sedangkan fakor yang menghambat terjadinya pengembangan di SMP An-Nir Bululawang Malang yaitu berasal dari (1) sulit membagi waktu peserta didik di sekolah dan di pesantren, (2) pola pikir kepala sekolah dan kiai yang berbeda dalam mengambil kebijakan, (3) inkonsistensi dalam menjalankan program.

\section{PEMBAHASAN}

Hasil temuan penelitian mengenai profil kepala sekolah dan kiai yaitu latar belakang pendidikan, pengalaman organisasi, pengalaman kerja, usaha yang dimiliki. Hal ini sesuai dengan pendapat Victoria Neufeld (1996, dalam Desi Susiani, 2009: 41) profil merupakan grafik, diagram, atau tulisan yang menjelaskan suatu keadaan yang mengacu pada data seseorang atau proses kehidupan individu. Kepala Sekolah SMP An-Nur memiliki riwayat pendidikan mulai dari Madrasah Ibtida'iyah Kudat lor, kemudian melanjutkan ke jenjang Tsanawiyah yaitu Madrasah Tsanawiyah Gondanglegi, kemudian Aliyah masuk ke pondok pesantren An-Nur 2 sekaligus menjadi murid Madrasah Aliyah An-Nur. Lalu bapak kepala sekolah mengambil S1 Jurusan Pendidikan Agama Islam di STISIA Jakarta, kemudian melanjutkan S2 di Universitas Darul Ulum Jombang. Sedangkan Kiai Pondok Pesantren An-Nur 2 memiliki riwayat pendidikan mulai dari Madrasah Ibtida'iyah Al-Khoiriyah Gondanglegi, kemudian melanjutkan ke bangku Tsanawiyah yaitu Madrasah Tsanawiyah Al-Khoiriyah Gondanglegi, kemudian melanjutkan ke Aliyah An-Nur. Sedangkan untuk S1 mengambil Jurusan Bahasa dan Sastra Arab di STAIN Malang, kemudian melanjutkan S2 di Universitas Islam Lamongan Magister Agama,dan S3 Pasca Sarjana IAIN Sunan Ampel Surabaya. Kepala sekolah juga sebelum menjabat juga memiliki pengalaman dalam berorganisasi seperti MWC Nahdlatul 'Ulama, kemudian organisasi komite se-Kec Gondanglegi, kemudian organisasi kepala sekolah. Sedangkan kiai memiliki pengalaman organisasi seperti PMII, kemudian anggota pengurus MWC Nahdlatul 'Ulama. Kepala Sekolah SMP An-Nur dan Kiai Pondok Pesantren An-Nur 2 masing masing memiliki pengalaman kerja sebelum menjabat seperti sekarang. Pengalaman tersebut diantaranya menjadi guru di SMP An-Nur, menjadi guru PP An-nur, kemudian guru tafsir dan tasawuf pondok pesantren An-nur, Dosen MK Ulum-Al-Quran STIT Raden Rahmad Kepanjen, kemudian menjadi direktur Ma'had Al-Aly An-nur, Menjadi tenaga pengajar umul qur'an An-nur. Sehingga dari profil yang melatar belakangi kepala sekolah dan kiai membawa dampak pada individu kepala sekolah dan kiai yang sekarang memiliki kewibawaan dalam memimpin sehingga dapat menjadi model (uswatun hasanah) bagi warga pesantren dan warga sekolah.

Hasil temuan penelitian mengenai peran kepala sekolah dan kiai sebagai pemimpin pengembangan yaitu manajerial yaitu mengatur Sumber Daya Manusia dan Non Manusia agara dapat bekerja secara maksimal. Hal ini sesuai dengan pendapat Suhardiman (2011: 39) yang menyatakan tugas manajerial kepala sekolah berkaitan dengan pengelolaan semua sumber daya yang ada di sekolah. Kepala SMP An-Nur Bululawang Malang dibantu dengan dua wakil kepala sekolah dalam mengelola SDM sekolah. Hal tersebut dilakukan karena kepala sekolah merasa kurang mampu mengawasi dan mengelola SDM yang sangat besar jumlahnya. Untuk itu beliau mengajak wakil kepala sekolah dan staffnya untuk semua bekerja sama dalam mengelola SDM sekolah. Pelibatan warga sekolah dalam mengelola SDM sekolah akan memunculkan rasa memiliki dan tanggung jawab untuk mencapainya. Kemudian pengelolaan 
SDM tersebut juga diawasi oleh Kiai Pondok Pesantren An-Nur 2. Selanjutnya tugas kepala sekolah memberikan laporan dan menjaga komunikasi dengan kiai agar pengelolaan SDM berjalan dengan lancar. Kepala dan kiai juga memiliki peran sebagai model pemberi contoh (uswatun hasanah), yaitu kepala sekolah dan kiai memberikan contoh kepada warga sekolahnya terhadap program-progam baru. Peran kepala sekolah dan kiai dalam mengembangkan sekolah berdasarkan temuan penilitian yaitu sebagai pengambil keputusan. Sebagai pengambil keputusan kepala sekolah dan kiai berkoordinasi membahas program-program yang bisa dijalankan. Maju tidaknya program sekolah tergantung kepada pengambilan keputusan kepala sekolah dan kiai. Hasil yang diperoleh peneliti tersebut mengenai peran kepala sekolah dan kiai sebagai pengambil keputusan sesuai dengan pendapat Hadi (2011, dalam Mustiningsih, 2014: 2) pembuatan keputusan merupakan fungsi seorang pemimpin, pembuatan keputusan diperlukan pada semua tahapan kegiatan manajemen, baik pada saat perencanaan, implementasi, maupun pada tahap pengawasan terhadap hasil rencana agar hasil yang diperoleh sesuai dengan target. Maju tidaknya program sekolah tergantung kepada keputusan kepala sekolah dan kiai, karena usulan program yang diberikan oleh warga sekolah tidak dapat dikerjakan jika kepala sekolah maupun kiai tidak menyetujui program baru tersebut.

Strategi kepala sekolah dan kiai dalam melakukan pengembangan untuk meningkatkan kualitas pendidikan yaitu salah satunya dengan melakukan seleksi peserta didik untuk masuk dalam kelas idaman. Imron (2012: 43) menjelaskan bahwa sistem seleksi pada penerimaan peserta didik baru dapat digolongkan menjadi tiga macam, yaitu seleksi berdasarkan Daftar Nilai Ebta Murni (DANEM), berdasarkan Penelusuran Minat dan Kemampuan (PMDK), dan seleksiberdasarkan hasil tes masuk. Pada sistem seleksi kelas idaman, sekolah terlebih dahulu menentukan kriteria atau persyaratan yang harus dipenuhi oleh peserta didik agar dapat diterima di kelas idaman. Kepala sekolah bekerja sama dengan Universitas Negeri Malang dalam menyeleksi peserta didik calon kelas idaman. Hal ini dilakukan untuk meningkatkan prestasi akademik dan non-akademik SMP An-Nur. Salah satu strategi pengembangan untuk peningkatan kualitas pendidikan di SMP An-Nur yaitu dengan menumbuhkan budaya sekolah. Menurut Kurnia \& Qomaruzzaman (2012: 24) bahwa "perubahan positif yang terjadi pada suatu sekolah hanya akan terjadi jika seluruh subjek sekolah memahami sifat budaya sekolahnya sendiri dengan baik, baik yang tampak maupun tidak tampak atau yang formal maupun informal". Pengembangan yang terjadi di sekolah akan diketahui apabila warga sekolah tersebut memahami budaya yang ada di sekolah tersebut. Kepala sekolah menciptakan budaya sekolah yaitu one day one hadist, istigosah, dan budaya tausiyah. Budaya tersebut diciptakan oleh kepala sekolah selain sebagai identitas sekolah yang berada dibawah naungan pondok pesantren, juga bertujuan untuk membentuk perilaku baik dan religius pada warga sekolahnya. Kepala sekolah dan kiai juga memperbaiki manajemen peserta didik di SMP An-Nur Bululawang dengan memperketat kedisiplinan peserta didik. Terdapat tiga teknik pembinaan disiplin menurut Imron (2012: 174) yang dapat diterapkan yaitu external control, inner control, dan cooperative control. Tata tertib yang ada di SMP An-Nur Bululawang Malang salah satunya yaitu dengan membuat peraturan bahwa peserta didik yang meninggalkan sekolah dan pesantren selama 3 hari akan diberi peringatan dan bisa dikeluarkan. Dari peraturan tersebut dapat diketahui bahwa SMP An-Nur menerapkan teknik external control untuk mendisiplinkan peserta didiknya. Kepala sekolah dan kiai membuat sejumlah peraturan kedisiplinan yang harus dijalankan. Apabila ada peserta didik yang melanggar peraturan, peserta didik harus menerima konsekuensinya yaitu berupa hukuman. Hukuman yang diberikan sesuai dengan poin pelanggaran. Hal ini dilakukan oleh kepala sekolah sebagai salah satu strategi untuk meningkatkan kualitas pendidikan melalui pengembangan.

Kepala sekolah dan kiai juga memperbaiki manajemen sumber daya manusia yang ada di SMP An-Nur Bululawang Malang dengan melakukan rekrutmen guru baru yang diutamakan alumni dan berpaham Nahdlatul 'Ulama. Sesuai dengan pendapat Mulyasa (2012: 64) "untuk mendapatkan guru dan staf yang sesuai dengan kebutuhan, dilakukan kegiatan rekrutmen, yaitu usaha mencari dan mendapatkan calon-calon guru dan staf yang memenuhi syarat sebanyak mungkin untuk kemudian dipilih calon terbaik dan tercakap". Kepala Sekolah SMP An-Nur Bululawang Malang melakukan rekrutmen guru baru dengan alasan bertambah banyaknya jumlah peserta didik. Akhirnya kepala sekolah memutuskan untuk melakukan rekrutmen guru baru dengan syarat harus lulusan universitas 
ternama di Malang, dan berpaham Nahdlatul Ulama. Mulyasa (2012: 67) mengemukakan bahwa pengembangan guru dan staff perlu dilakukan pada setiap sekolah untuk memastikan bahwa mereka tetap dapat mempertahankan kualitas profesionalitasnya sesuai dengan keutuhan sekolah. Cara yang dapat dilakukan yaitu dengan mengikutsertakan guru dan staff pada kegiatan pelatihan, penataran, seminar, dan workshop yang diadakan oleh sekolah sendiri atupun oleh lembaga lain. Kepala SMP AnNur juga melakukan supervisi sebagai salah satu strategi pengembangan untuk peningkatan kualitas pendidikan. Supervisi adalah bantuan profesional kepada guru melalui siklus perencanaan yang sistematis, pengamatan yang cermat, dan umpan balik yang objektif dan segera, yang bertujuan untuk meningkatkan kemampuan profesional guru dan meningkatkan kualitas pembelajaran (Mulyasa, 2012: 249). Supervisi yang dilakukan oleh Kepala SMP An-Nur Bululawang Malang yaitu dengan melakukan pengecekan kelas, kelengkapan mengajar guru, langsung berkeliling ke kelas-kelas untuk melihat apakah pembelajaran yang dilakukan sesuai dengan skenario yang dibuat. Kemudian membentuk tim supervisi yang diisi oleh Kaur dan guru-guru senior.

Program yang dihasilkan oleh kepala sekolah dan kiai dalam pengembangan kualitas pendidikan di sekolah berdasarkan pada kebutuhan sekolah yaitu program kelas idaman untuk membentuk karakter peserta didik yang berakhlakul karimah dan berprestasi dibidang akademik dan non-akademik, serta membuat E-Report untuk memudahkan wali murid mengakses dan melihat hasil belajar anaknya tanpa harus datang ke SMP An-Nur mengingat tempat asal peserta didik SMP An-Nur kebanyakan dari luar Kabupaten Malang. Prawirosentono (2002: 23) kinerja adalah usaha yang dilakukan oleh seseorang dari pekerjaan yang telah dikerjakan sesuai tugas yang diberikan oleh suatu organisasi sesuai dengan wewenang dan tanggung jawab masing-masing dalam rangka mencapai tujuan organisasi secara legal, tidak melanggar hukum dan sesuai dengan moral maupun etika. Warga SMP An-Nur Bululawang Malang dapat menikmati dan menerima hasil dari program yang telah dibuat oleh kepala sekolah dan kiai, karena program tersebut dinilai sangat bermanfaat. Program kelas idaman yang dibuat bermanfaat bagi warga sekolah untuk membentuk karakter religius dan berprestasi terutama pada peserta didik, selain pada warga sekolah sendiri, program tersebut bermanfaat bagi masyarakat pesantren, karena program kelas idaman membuat santri Pondok Pesantren An-Nur 2 tidak hanya pandai dan berprestasi dalam bidang keagamaan, namun juga pandai dan berprestasi dalam bidang pendidikan formal, serta memunculkan santri yang berkompeten dan memiliki intelektual yang tinggi. Sedangkan program yang dibuat dengan membuat E-Report bermanfaat untuk meningkatkan standar nilai peserta didik. Kemudian memudahkan bagi orangtua melihat hasil belajar anaknya.

Faktor pendukung kepemimpinan pengembangan yang dilakukan oleh kepala sekolah dan kiai dalam peningkatan kualitas pendidikan di SMP An-Nur dari internal yaitu kepemimpinan kepala sekolah yang terus mendorong warganya untuk berubah dan membuat program-program baru, dukungan dari pondok pesantren, kepemimpinan kiai, alumni, dan sarana prasarana sekolah yang memadai. Hasil tersebut sesuai dengan pendapat Andreson (dalam Wibowo, 2012:93) yang menyatakan faktor penggerak yang dapat memengaruhi terjadinya perubahan salah satunya yaitu pola pikir dari pimpinan. Pola pikir tersebut meliputi pandangan, asumsi, keyakinan atau mental model yang menyebabkan orang berperilaku dan bertindak seperti yang diinginkan. Pola pikir Kepala SMP An-Nur Bululawang Malang yang mempunyai keinginan untuk meningkatkan kualitas pendidikan di sekolah dengan membuat program-program baru menyebabkan pengembangan dapat terjadi di SMA Nasional Malang. Sedangkan faktor pendukung pengembangan di SMP An-Nur Bululawang Malang dari pihak eksternal yaitu banyak orangtua yang menginginkan anaknya dapat bersekolah berbasis pesantren pada jenjang SMP, namun tidak sedikit pula dari mereka yang mendaftar karena biaya yang murah, serta faktor yang datang dari lembaga pendidikan lain terutama sekolah swasta dan negeri yang lebih baik dan diminati masyarakat. Sesuai dengan pendapat Robbins (dalam Wibowo 2012: 91) yang menyatakan bahwa faktor yang memengaruhi organisasi untuk berubah yaitu adanya persaingan dengan organisasi-organisasi lainnya.

Hambatan yang ditemui kepala sekolah dan kiai ketika melakukan pengembangan di SMP AnNur Bululawang Malang datang dari internal sekolah yaitu membagi waktu santri yang juga sekaligus peserta didik dengan kegiatan di pondok pesantren, pola pikir kepala sekolah dan kiai yang berbeda dalam mengambil kebijakan, dan konsistensi dalam menjalankan program sekolah. Hambatan ini sesuai 
dengan pendapat yang dikemukankan oleh Kaufman (1985: 8) menegaskas kegagalan suatu organisasi dalam melakukan pengembangan disebabkan oleh beberapa faktor berikut yaitu, a) hasrat untuk mempertahankan kestabilan hidup bersama; b) pertimbangan atas lawan-lawan yang mungkin dihadapi untuk mengadakan pengembangan, kelompok oposisi pengembangan akan datang dari dalam maupun dari luar organisasi, baik secara perseorangan maupun berkelompok; dan c) ketidakmampuan untuk mengadakan pengembangan.

\section{SIMPULAN DAN SARAN}

\section{Simpulan}

Kepala sekolah adalah seseorang yang memiliki tugas untuk memimpin suatu sekolah yang digunakan untuk melaksanakan proses belajar mengajar. Seseorang tidak bisa secara langsung tiba-tiba menjadi kepala sekolah, ada proses yang harus ditempuh. Kepala Sekolah di SMP An-Nur ditunjuk langsung oleh kiai pengasuh pondok pesantren. Yayasan Pondok Pesantren An-Nur juga memiliki syarat tertentu untuk seseorang diangkat sebagai kepala sekolah. Syarat yang utama adalah alumni Pondok Pesantren An-Nur. Beda halnya dengan seorang kiai, jika dalam kepemimpinan kepala sekolah memiliki periode waktu dalam menjabat, seorang kiai tidak memiliki sebuah periode, kiai adalah kiai yang memimpin pondok pesantren sampai akhir hayat. Peran kepala sekolah dan kiai sebagai pemimpin pengembangan yaitu, manajerial yaitu mengatur Sumber Daya Manusia dan Non Manusia agara dapat bekerja secara maksimal, kepala sekolah dan kiai memberikan contoh kepada warga sekolahnya terhadap programprogam baru, kepala sekolah dan kiai berperan sebagai pengambil keputusan. Strategi yang digunakan oleh kepala sekolah dan kiai dalam melakukan pengembangan kualitas pendidikan yaitu memperbaiki fasilitas sarana dan prasaran sekolah, melakukan koordinasi dengan kepala sekolah mengenai program-program yang akan dijalankan, membuat kebijakan dengan mengangkat dua wakil kepala sekolah untuk membantu tugas kepala sekolah dalam mengawasi warga sekolah, menumbuhkan budaya religius sekolah dengan program One Day One Hadist, melakukan rekruitmen guru baru serta melakukan pengembangan pada tenaga pendidik dengan mengadakan pelatihan-pelatihan, mendisiplinkan peserta didik melalui guru tatib, mengadakan program bimbingan belajar untuk kelas IX dalam rangka mengahadapi UN, dan membuat program kelas idaman, serta membuat E-Report untuk memudahkan wali murid mengakses dan melihat hasil belajar. Faktor pendukung kepemimpinan pengembangan yang dilakukan oleh kepala sekolah dan kiai dalam peningkatan kualitas pendidikan di SMPAn-Nur dari internal yaitu kepemimpinan kepala sekolah yang terus mendorong warganya untuk berubah dan membuat program-program baru, dukungan dari pondok pesantren, kepemimpinan kiai, alumni, dan sarana prasarana sekolah yang memadai. Sedangkan faktor pendukung pengembangan di SMP An-Nur Bululawang Malang dari pihak eksternal yaitu banyak orangtua yang menginginkan anaknya dapat bersekolah berbasis pesantren pada jenjang SMP, namun tidak sedikit pula dari mereka yang mendaftar karena biaya yang murah, serta faktor yang datang dari lembaga pendidikan lain terutama sekolah swasta dan negeri yang lebih baik dan diminati masyarakat. Hambatan yang ditemui kepala sekolah dan kiai ketika melakukan pengembangan di SMP An-Nur Bululawang Malang yaitu membagi waktu santri yang juga sekaligus peserta didik dengan kegiatan di pondok pesantren, pola pikir kepala sekolah dan kiai yang berbeda dalam mengambil kebijakan, dan konsistensi dalam menjalankan program sekolah. 


\section{Saran}

Berdasarkan kesimpulan di atas terdapat beberapa saran peneliti lain, melakukan penelitian pada substansi sama tetapi pada tinjauan yang berbeda

\section{DAFTAR RUJUKAN}

Andriani, D. 2008. Peran Kepala Sekolah Dalam Upaya Mewujudkan Perubahan Sekolah. (Online), (http:// media.neliti.com/media/publications/114328-ID-peran-kepala-sekolah-dalam-upaya-mewujud.pdf), diakses pada 24 Juni 2018.

Imron, A. 2012. Manajemen Peserta Didik Berbasis Sekolah. Jakarta: Bumi Aksara.

Kaufman, H. 1985. Limits Of Organization Change. Alabama: University of Alabama Press.

Mulyasa. 2012. Manajemen dan Kepemimpinan Kepala Sekolah. Jakarta: PT Bumi Aksara.

Robbins, S. 2006. Perilaku Organisasi. Edisi Bahasa Indonesia. Jakarta: PT. Kelompok Gramedia.

Suharsaputra, U. 2016. Kepemimpinan Inovasi Pendidikan (Mengembangkan Spirit Entrepreneurship Menuju Learning School). Bandung: PT Refika Aditama.

Supriyanto, A. 2009. Manajemen Perubahan: Bahan Ajar Berbasis Benchmarking. Malang: Universitas Negeri Malang.

Wibowo. 2012. Manajemen Perubahan. Edisi Ketiga. Jakarta: Rajawali Pers. 